\title{
Changes During Passive Recovery In Lower Limbs Tiredness After Strenuous Workout
}

\author{
Supriyo Mondal ${ }^{1} \&$ L. N. Sarkar ${ }^{2}$ \\ ${ }^{1}$ Ph.D. Scholar, L.N.I.P.E., Gwalior, Madhya Pradesh. \\ ${ }^{2}$ Professor, Registrar, L.N.I.P.E., Gwalior, Madhya Pradesh
}

\begin{abstract}
Lower limbs tiredness is a widely accepted indicator for recovery state prediction. The study was designed and purposed to know the rate and trend of lower limbs tiredness recovery after strenuous workout in passive state. Ten athletes from LNIPE, Gwalior having almost similar anthropometric measurements, physiological capacity, chronological age(18-19 year), training age(5-6 year), event(sprinters) etc. residing in same campus having similar daily routine were selected as participant in this experiment. The experiment was conducted in a highly controlled environment using sophisticate equipments. Target Heart Rate Zone of the workout lasting for 20 minutes was 80\%-90\% of their Maximum Heart Rate. Three readings including pre, post and 30 minutes post workout was considered for both the two tests (Isometric Leg Strength Test and Sergeant Jump Test) selected for the purpose. rANOVA was employed separately to derive out meaningful information from the raw data. In both the tests well controlled workout for 20 minutes resulted in significant increase state of post workout readings. With passage of time after 30 minutes post passive recovery there was no improvement in state of tiredness. Thus scope of future research is there in planning out means and methods to promote lower limbs tiredness recovery during this post recovery period.
\end{abstract}

Keyword: Isometric Leg Strength Test, Sergeant Jump Test, Recovery, rANOVA

\subsection{Background}

\section{INTRODUCTION}

Strength is a determinant factor for optimal performance ${ }^{1}$ in most of the sport in present ultra competitive era. It is produced due to contraction of muscles. More vigorous, coordinated and precise the muscle contraction, better the production of force is. Exceptional apart, most of the sporting events demanding immediate and powerful force production, utilizes the lower limbs for the same purpose. Thus the accumulation of metabolic waste is also too much in the lower limbs during sport activities performed above lactate threshold level for an ample duration of time. ${ }^{234}$

\subsection{Purpose}

Rational behind conducting this study was to know the rate and trend of lower limbs tiredness after strenuous workout followed by a passive recovery, as it may help to aid information in the area of sport recovery for planning further researches in future.

\subsection{Participants}

\section{METHODOLOGY}

Ten athletes from LNIPE, Gwalior having almost similar anthropometric measurements, physiological capacity, chronological age(18-19 year), training age(5-6 year), event(sprinters) etc. residing in same campus having similar daily routine were selected as participant in this experiment.

\subsection{Criterion Measures}

Explosive and isometric leg strength was selected to be studied at different time interval with the help of two widely accepted tests i.e. sergeant jump test ${ }^{56}$ and isometric leg strength test ${ }^{7}$.

\subsection{Administration of the Experiment}

The experiment was conducted in the fitness center of LNIPE, Gwalior having controlled temperature $\left(28^{\circ} \mathrm{C}\right)$ inside $\mathrm{A} / \mathrm{C}$ fitness centre during the month of August, 2013. Equipments used were Treadmill (FreeMotion co.), Heart Rate Monitor Watch (Garmin Forerunner), Room Temperature Thermometer (Omsons), Portable Leg Dynamometer etc. The participants were informed about the pros and cons of experiment to be conducted in detail and their willing concern was taken on paper. The experiment started with a mild warm up session consisting of self stretching. The treadmill intensity was manipulated in a slow progression manner to such that the heart rate remains within the Target Heart Rate Zone(THR) of 80\%-90\% of their Maximum Heart $\operatorname{Rate}^{8}\left(\mathrm{HR}_{\max }=208-(0.7 \times\right.$ age $\left.)\right)$ for at least 16 minutes of the total 20 minutes of duration during treadmill 
workout. Karvonen formula ${ }^{9}\left(\mathrm{THR}=\left(\left(\mathrm{HR}_{\max }-\mathrm{HR}_{\text {rest }}\right) \times \%\right.\right.$ intensity $\left.)+\mathrm{HR}_{\text {rest }}\right)$ for calculating target heart rate was used. Participants were free to withdraw themselves at any point of workout. Best of two readings on leg strength with both the test were taken at regular interval just before workout, just after workout and 30 minutes after workout. Post recovery till the last reading the participants kept sitting idle. ${ }^{10}$

\subsection{Statistical Technique}

The study followed repeated measure design. For analyzing the obtained data and derive the meaningful information from it descriptive statistics, one way repeated measure analysis of variance (rANOVA) and bonferroni post hoc test was conducted using IBM SPSS-17 software ${ }^{11}$. Level of significance choosen was 0.05 .

III. RESULTS AND FINDINGS

\begin{tabular}{|c|c|c|c|c|c|c|}
\hline \multicolumn{7}{|c|}{ Table 1: Descriptive Statistics of Leg Strength } \\
\hline & \multicolumn{3}{|c|}{ Isometric Leg Strength Test } & \multicolumn{3}{|c|}{ Sergeant Jump Test } \\
\hline Reading at Different Time & Mean & SD & SEM & Mean & SD & SEM \\
\hline Leg Strength Pre Activity & 182.80 & 25.90 & 8.19 & 57.80 & 7.08 & 2.24 \\
\hline Leg Strength Post Activity & 167.10 & 20.01 & 6.33 & 52.70 & 7.35 & 2.32 \\
\hline Leg Strength Post Recovery & 171.10 & 31.24 & 9.88 & 54.10 & 8.96 & 2.83 \\
\hline
\end{tabular}

Table 1 indicates descriptive scores of mean \& standard deviation of Isometric Leg Strength Test \& Sergeant Jump Test of the participants.

\begin{tabular}{|c|c|c|c|c|c|c|c|}
\hline \multirow{3}{*}{$\begin{array}{l}\text { Within Subjects } \\
\text { Effect }\end{array}$} & \multicolumn{7}{|c|}{ Table 2: Mauchly's Test for Testing Assumption of Sphericity } \\
\hline & \multirow{2}{*}{ Mauchly's W } & \multirow{2}{*}{$\begin{array}{l}\text { Approx. } \\
\text { Chi- } \\
\text { Square }\end{array}$} & \multirow[t]{2}{*}{ df } & \multirow{2}{*}{$\begin{array}{c}\text { P- } \\
\text { Value }\end{array}$} & \multicolumn{3}{|c|}{ Epsilon } \\
\hline & & & & & $\begin{array}{l}\text { Greenhouse- } \\
\text { Geisser }\end{array}$ & $\begin{array}{l}\text { Huynh- } \\
\text { Feldt }\end{array}$ & $\begin{array}{l}\text { Lower- } \\
\text { bound }\end{array}$ \\
\hline $\begin{array}{l}\text { Isometric Leg } \\
\text { Strength Test }\end{array}$ & $0.43^{*}$ & 6.77 & 2 & 0.034 & 0.64 & 0.69 & 0.50 \\
\hline Sergeant Jump Test & 0.73 & 2.57 & 2 & 0.276 & 0.78 & 0.92 & 0.50 \\
\hline
\end{tabular}

* Significant at 0.05 level

For Isometric Leg strength Test, Mauchly's Test of Sphericity is significant as P-Value is less than 0.05 , which means assumption of sphericity has been violated. Again as the Epsilon value is less than 0.75 thus Greenhouse-Geisser correction will be used for referring significance of the F ratio for interpreting results in rest of the study for this particular strength test. In case of Sergeant Jump Test assumption of sphericity has been met as Mauchly's Test of Sphericity is nonsignificant having P-Value more than 0.05 .

\begin{tabular}{|c|c|c|c|c|c|c|}
\hline \multicolumn{7}{|c|}{ Table 3: Tests of Within-Subjects Effects of Leg Strength } \\
\hline Test & & $\begin{array}{l}\text { Type III Sum } \\
\text { of Squares }\end{array}$ & $\mathrm{df}$ & $\begin{array}{l}\text { Mean } \\
\text { Square }\end{array}$ & $\mathrm{F}$ & $\begin{array}{c}\text { P- } \\
\text { Value }\end{array}$ \\
\hline $\begin{array}{l}\text { Isometric Leg } \\
\text { Strength Test }\end{array}$ & $\begin{array}{l}\text { Greenhouse- } \\
\text { Geisser }\end{array}$ & 1331.27 & 1.27 & 1045.71 & 4.36 & 0.053 \\
\hline $\begin{array}{l}\text { Error(Isometric Leg } \\
\text { Strength Test) }\end{array}$ & $\begin{array}{l}\text { Greenhouse- } \\
\text { Geisser }\end{array}$ & 2748.73 & 11.46 & 239.90 & & \\
\hline Sergeant Jump Test & $\begin{array}{l}\text { Sphericity } \\
\text { Assumed }\end{array}$ & 138.87 & 2 & 69.43 & $18.25^{*}$ & 0.000 \\
\hline $\begin{array}{l}\text { Error(Sergeant Jump } \\
\text { Test) }\end{array}$ & $\begin{array}{l}\text { Sphericity } \\
\text { Assumed }\end{array}$ & 68.47 & 18 & 3.80 & & \\
\hline
\end{tabular}

*Significant at 0.05 level.

Perusal of Table 3 shows the results of both the within-subjects variable. It reveals that there lies no statistical significant difference in Isometric Leg Strength Test, whereas in case of Sergeant Jump Test significant difference is present as the significance of $\mathrm{F}$ in the first case is 0.053 which is more than the criterion value of 0.05 , and in the later case is 0.00 which is less than the criterion value of 0.05 . We can, therefore, conclude that there was a significant difference between the leg strength readings at different time point calculated by Sergeant Jump Test, but there was no difference between leg strength readings at different time point calculated by Isometric Leg Strength Test. However, this test does not tell us exactly in between which readings the difference exists. For availing this detail information we conducted Bonferroni post Hoc test. 
Changes During Passive Recovery In Lower Limbs Tiredness After Strenuous Workout

\begin{tabular}{|c|c|c|c|c|c|c|c|}
\hline & & Table 4: Pairwise & omparisons of Ma & ginal Leg S & ength Mean & & \\
\hline & \multirow[t]{2}{*}{ (I) Leg Strength } & \multirow[t]{2}{*}{ (J) Leg Strength } & \multirow[t]{2}{*}{$\begin{array}{c}\text { Mean } \\
\text { Difference (I-J) }\end{array}$} & \multirow[t]{2}{*}{ Std. Error } & \multirow[t]{2}{*}{ P-Value } & \multicolumn{2}{|c|}{$\begin{array}{c}95 \% \text { Confidence } \\
\text { Interval for Difference }\end{array}$} \\
\hline & & & & & & $\begin{array}{l}\text { Lower } \\
\text { Bound }\end{array}$ & $\begin{array}{l}\text { Upper } \\
\text { Bound }\end{array}$ \\
\hline \multirow{3}{*}{ 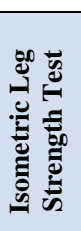 } & Pre Activity & Post Activity & $15.70^{*}$ & 5.09 & 0.039 & 0.76 & 30.64 \\
\hline & Pre Activity & Post Recovery & $11.70^{*}$ & 3.64 & 0.032 & 1.02 & 22.38 \\
\hline & Post activity & Post Recovery & -4.00 & 7.24 & 1.000 & -25.24 & 17.24 \\
\hline \multirow{3}{*}{ 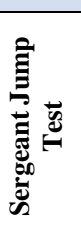 } & Pre Activity & Post Activity & $5.10^{*}$ & 0.72 & 0.000 & 2.98 & 7.22 \\
\hline & Pre Activity & Post Recovery & $3.70^{*}$ & 1.08 & 0.022 & 0.55 & 6.85 \\
\hline & Post activity & Post Recovery & -1.40 & 0.78 & 0.316 & -3.68 & 0.88 \\
\hline
\end{tabular}

* Significant at 0.05 level

The rows having mean difference followed by star $(*)$ in the above Table 4 indicates the presence of significant difference between various reading points of both the leg strength test. An interesting finding is though the main effect for Isometric Leg Strength Test was found to be nonsignificant previously in Table 3, but Pairwise Comparisons of Marginal Means of the same shows there exist significant difference with pre activity reading to post activity readings and post recovery reading. In case of Sergeant Jump Test too significant difference was found with pre activity reading to post activity readings and post recovery reading.

\section{DISCUSSION OF FINDINGS}

Within the limitation of the study, the findings of leg strength test by both the tests reveals that after significant decrease in it due to 20 minutes of highly controlled workout at $80 \%$ $90 \%$ of their $\mathrm{HR}_{\max }$, it did not recovered significantly till 30 minutes post workout, as the pre workout to post workout and post passive recovery readings remained significantly different in both the tests. The rate and trend of tiredness of lower limbs after strenuous workout followed by a passive recovery is shown in Figure 1, for Isometric Leg Strength Test and Figure 2, for Sergeant Jump Test. Thus the sports scientists may try out some specific recovery modules, strategies, interventions, etc. for catalyzing the rate of immediate recovery as in most of the games and sports i.e. judo, boxing, volleyball, swimming, cycling, and many more the demand of immediate recovery is very much due to conduction of repeated bouts or sessions in a single day for overcoming administrative limitations.
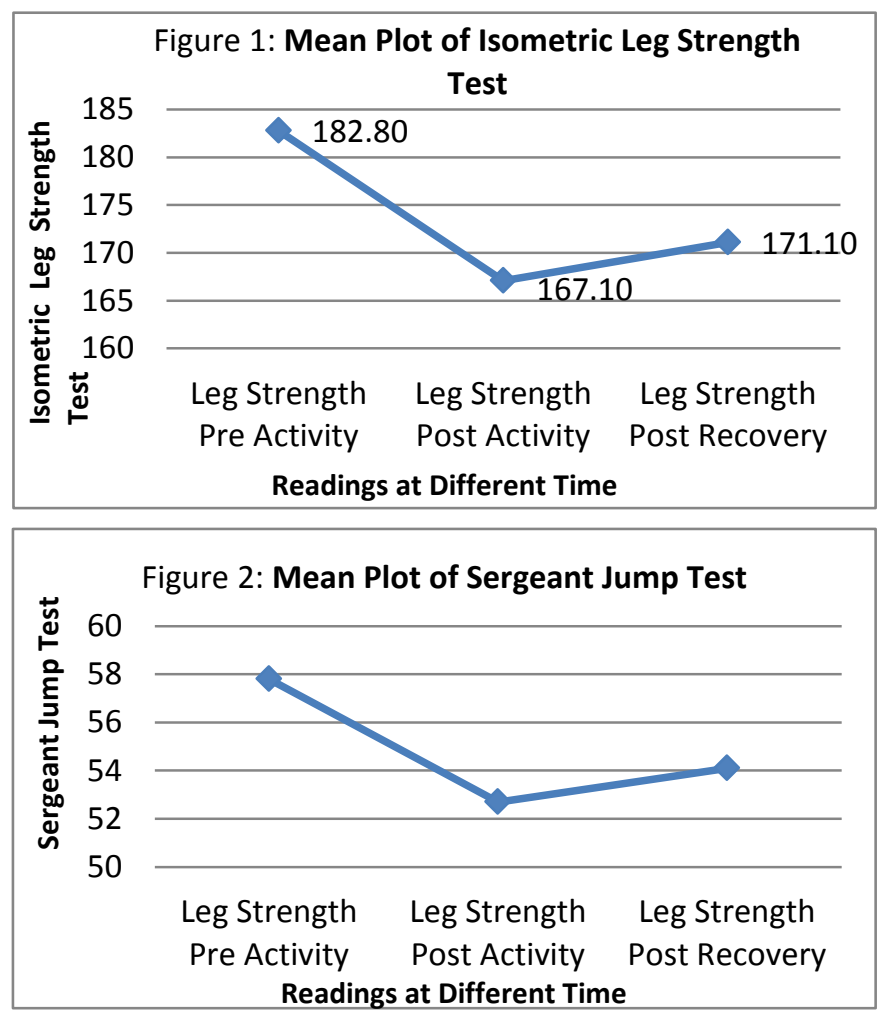

\section{CONClusion}

In both the tests Isometric Leg Strength Test and Sergeant Jump Test for assessing tiredness of lower limbs after strenuous well controlled workout for 20 minutes we found significant increase state of post workout readings. With passage of time after 30 minutes post passive recovery there was no improvement in state of tiredness. Thus scope of future research is there in planning out means and methods to promote strength recovery during this post recovery period. 


\section{ACKNOWLEDGEMENT}

Sincere \& honest thanks to Prof. Manika Debnath, HOD, DHSF, LNIPE, and Shri K.K. Bhatia, Assistant Registrar (Procurement \& Finance), LNIPE for extending their help in providing equipments and facilities required to accomplish the research smoothly. I also thank the participants for their voluntary interest in the experiment.

\section{REFERENCES}

[1]. Thomas R. Baechle,. (2008). Essentials of Strength Training and Conditioning-3rd Edition, NSCA -National Strength \& Conditioning Association.

[2]. Dagmar A. Brüggemann, Jens Risbo, Stefan G. Pierzynowski, and Adrian P. Harrison., Muscle Contraction and Force: the Importance of an Ancillary Network, Nutrient Supply and Waste Removal, Int J Mol Sci. 2008 August; 9(8): 1472-1488. doi: 10.3390/ijms 9081472

[3]. Knicker, A. J., Renshaw, I., Oldham, A.R.H., Cairns, S.P. (2011). Interactive processes link the multiple symptoms of fatigue in sport competition. Sports Medicine., 2011; 41(4): 307-328.

[4]. Girard, O., Lattier, G., Micallef, J., and Millet, G., Changes in exercise characteristics, maximal voluntary contraction, and explosive strength during prolonged tennis playing. British Journal of Sports Medicine., 2006; 40:521-526

[5]. Johnson DL and Bahamonde R.. Power Output Estimate in University Athletes. Journal of strength and Conditioning Research, $1996 ; 10(3), 161-66$.

[6]. Linnamo, V., Hakkinen, K., Komi, P.V., Neuromuscular fatigue and recovery in maximal compared to explosive strength loading. European journal of applied physiology., 1998; 77: 176-181.

[7]. Carpenter MR, Carpenter RL, Peel J, Zukley LM, Angelopoulou KM, Fischer I, Angelopoulos TJ, Rippe JM., The reliability of isokinetic and isometric leg strength measures among individuals with symptoms of mild osteoarthritis. J Sports Med Phys Fitness. 2006 Dec; 46(4):585-9.

[8]. Tanaka, Hirofumi; Monahan, Kevin D; Seals, Douglas R., "Age-predicted maximal heart rate revisited". Journal of the American College of Cardiology. 2001; 37 (1): 153-6. doi:10.1016/S0735-1097(00)01054-8. PMID 11153730

[9]. Karvonen JJ, Kentala E, Mustala O. The effects of training on heart rate: a "longitudinal" study. Ann Med Exp Biol Fenn., 1957; 35: 307-15.

[10]. Bompa, Tudor O, (1994). Periodization: Theory and Methodology of Training 4th edition, United States of America, Human Kinetics Publishers.

[11]. Verma J P., (2011). Statistical Methods for Sports and Physical Education,Tata McGraw Hill Education Private Ltd. 